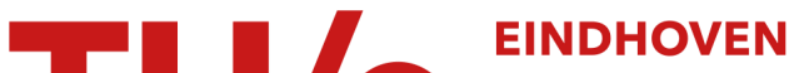 UNIVERSITY OF TECHNOLOGY
}

\section{Poled polymers for frequency doubling of diode lasers}

Citation for published version (APA):

Rikken, G. L. J. A., Seppen, C. J. E., Nijhuis, S., \& Meijer, E. W. (1991). Poled polymers for frequency doubling of diode lasers. Applied Physics Letters, 58(5), 435-437. https://doi.org/10.1063/1.104625

DOI:

10.1063/1.104625

Document status and date:

Published: 01/01/1991

\section{Document Version:}

Publisher's PDF, also known as Version of Record (includes final page, issue and volume numbers)

\section{Please check the document version of this publication:}

- A submitted manuscript is the version of the article upon submission and before peer-review. There can be important differences between the submitted version and the official published version of record. People interested in the research are advised to contact the author for the final version of the publication, or visit the $\mathrm{DOI}$ to the publisher's website.

- The final author version and the galley proof are versions of the publication after peer review.

- The final published version features the final layout of the paper including the volume, issue and page numbers.

Link to publication

\section{General rights}

Copyright and moral rights for the publications made accessible in the public portal are retained by the authors and/or other copyright owners and it is a condition of accessing publications that users recognise and abide by the legal requirements associated with these rights.

- Users may download and print one copy of any publication from the public portal for the purpose of private study or research.

- You may not further distribute the material or use it for any profit-making activity or commercial gain

- You may freely distribute the URL identifying the publication in the public portal.

If the publication is distributed under the terms of Article $25 \mathrm{fa}$ of the Dutch Copyright Act, indicated by the "Taverne" license above, please follow below link for the End User Agreement:

www.tue.nl/taverne

Take down policy

If you believe that this document breaches copyright please contact us at:

openaccess@tue.nl

providing details and we will investigate your claim. 


\title{
Poled polymers for frequency doubling of diode lasers
}

\author{
G. L. J. A. Rikken, C. J. E. Seppen, S. Nijhuis, and E. W. Meijer ${ }^{\text {a) }}$ \\ Philips Research Laboratories, P.O. Box 80000, NL-5600 JA Eindhoven, The Netherlands
}

(Received 28 June 1990; accepted for publication 2 November 1990)

We report on the design and characterization of methylmethacrylate copolymers with nonlinear optical 4-alkoxy-4'-alkylsulfone stilbene sidechains, which are transparent down to $410 \mathrm{~nm}$. A fairly stable, polar orientation has been obtained by means of electric field poling, resulting in a reasonably high nonlinearity $\left(d_{33} \leqslant 9 \mathrm{pm} / \mathrm{V}\right)$.

Aligning polar molecules imbedded in a polymer matrix by means of a high electric field, as demonstrated by Havinga and van Pelt, ${ }^{1}$ can introduce a significant polar orientation. This makes these materials suitable for secondorder nonlinear optical (NLO) effects, like electro-optical modulation $\mathrm{n}^{2,3}$ and second-harmonic generation (SHG).$^{3,4}$ Especially for this last purpose polymeric materials are very promising, as they can easily be applied in optical waveguide geometries, thereby transforming low powers like those emitted by diode lasers into high intensities and consequently giving high conversion efficiencies. However, up to now no poled polymer has been reported that can be used to double the frequency of the emission of the common AlGaAs-GaAs laser diodes $(\lambda \sim 820 \mathrm{~nm})$. In this letter we describe polymers that were specifically designed for this purpose and present the optical properties that affect their performance in this specific application.

The major requirements for the NLO moiety are a high first-order hyperpolarizability $\beta(-2 \omega ; \omega, \omega)$ and complete transparency at both the fundamental and the second-harmonic wavelength. As a small separation between the charge transfer (CT) band and the second harmonic gives a large resonant enhancement to $\beta$ (Ref. 3 ) a narrow CT band is obviously advantageous. After having screened a large number of chromophores for their linear and nonlinear optical properties, ${ }^{5}$ we have selected some stilbene compounds containing an alkylsulfone group as electron acceptor and an alkoxy group as electron donor, as favorable candidates. Some relevant properties of these molecules are listed in Table I.

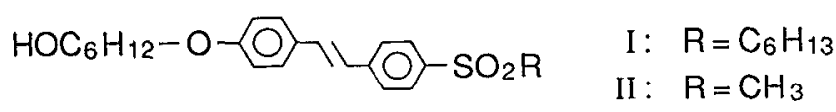

Sidechain copolymers with methylmethacrylate were synthesized, as described elsewhere, ${ }^{6}$ with various concentrations of the NLO moiety. The sidechain concentration was limited by the occurrence of semi-crystallinity, giving rise to large scattering losses. This occurred above 25 mass $\%$ for compound I and 50 mass \% for compound II. Figure 1 shows the solid-state absorption spectrum of such a polymer, with the CT band of the NLO moieties centered around $340 \mathrm{~nm}$. At $800 \mathrm{~nm}$, waveguiding in thin films of

\footnotetext{
'Present address: DSM Research, P.O. Box 18, NL-6160 MD Geleen, The Netherlands.
}

these polymers over many centimeters was observed. The refractive indices $n$ of these materials were determined using quasi-waveguide techniques ${ }^{7}$ at several wavelengths and fitted to a Sellmeier dispersion formula. From this, the coherence length $L_{c}=\lambda /\left(n_{2 \omega}-n_{\omega}\right)$ can be easily determined. This parameter is essential for phase matching the second-harmonic wave to the fundamental one. At $820 \mathrm{~nm}$ we find a coherence length of $5.5 \mu \mathrm{m}$ for the $25 \%$ copolymer (II).

For poling experiments, thin-film samples were prepared by spin coating onto indium-tin oxide (ITO) covered glass substrates and overnight annealing at $370 \mathrm{~K}$ under vacuum. The electric field for poling was applied with a corona discharge ${ }^{8}$ at a temperature of $370 \mathrm{~K}$, which is about $20 \mathrm{~K}$ below the glass transition temperature of these polymers. Typical fields, as determined by a compensation technique ${ }^{8}$ were $1.2 \mathrm{MV} / \mathrm{cm}$. Equilibrium $d_{33}$ is reached in tens of seconds, after which the sample is cooled down to room temperature in $15 \mathrm{~min}$. The nonlinearity shows the expected linear dependence on NLO chromophore concentration (Fig. 2). Only at the highest concentration a (positive) deviation is found, which may be indicative of extra orientation due to some collective behavior of the chromophores. The highest value obtained was $9 \mathrm{pm} / \mathrm{V}$ at $820 \mathrm{~nm}$ for the $45 \%$ copolymer shortly after poling. This is comparable to the nonlinearities found in crystalline materials like $\mathrm{LiNbO}_{3}$ and KTP. The temporal stability of the nonlinearity, after the poling field was switched off, was fairly good, as shown in Fig. 3, if the sample was stored in a dry environment. The slow loss of nonlinearity is caused by relaxation of the orientation of the NLO groups and can be further suppressed by going to polymer backbones that allow for less local mobility. Storage at ambient conditions caused a rapid drop in $d_{33}$ after a few days, due to water diffusing into the polymer which acts as a plasticizer.

Fairly high birefringence, due to the chromophore orientation, has been reported for poled polymers. ${ }^{9,10}$ From prism coupling refractive index measurements, we found that the as-deposited films showed a larger refractive index for light polarized parallel to the plane of the film. For the

TABLE I. Properties of the NLO chromophore. No significant dependence on the alkyl chain lengths was observed.

\begin{tabular}{ccccc}
\hline$\lambda_{\max }(\mathrm{nm})$ & $\mu(\mathrm{D})$ & $1907 \mathrm{~nm}$ & $\begin{array}{c}\beta\left(10^{-30} \mathrm{esu}\right) \\
1064 \mathrm{~nm}\end{array}$ & $820 \mathrm{~nm}$ \\
\hline 335 & 6.5 & 10 & 24 & 45 \\
\hline
\end{tabular}




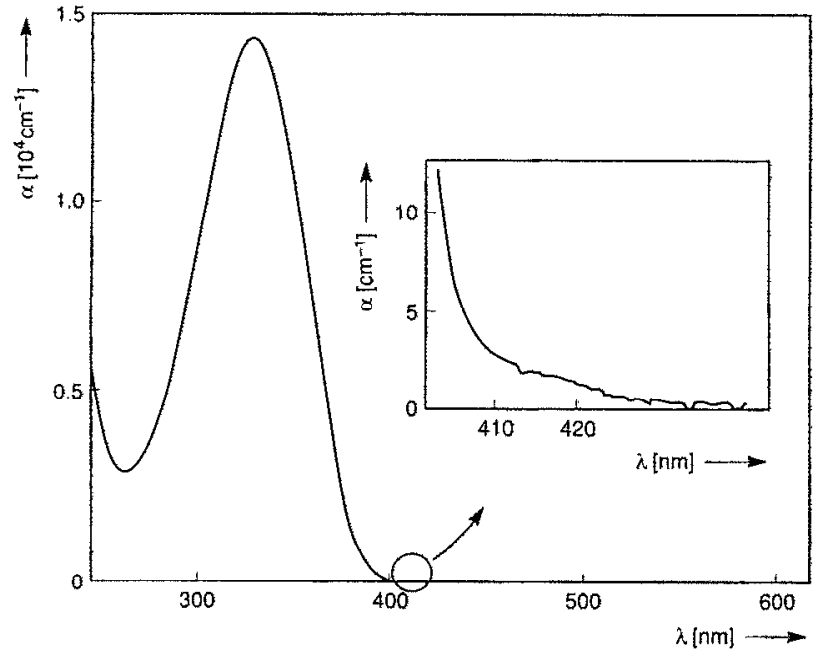

FIG. 1. Absorbance vs wavelength of a thin film of the $25 \%$ copolymer (II).

$25 \%$ polymer (II) this amounted to $n_{1}-n_{1}$ $\sim-2.10^{-3}$, probably due to flow induced alignment of the sidechains. On annealing at $370 \mathrm{~K}$ for $24 \mathrm{~h}$, this difference strongly decreased. Electric field poling introduced the expected positive birefringence, albeit too small for phase-matching purposes [for $25 \%$ (II) $n_{\perp}-n_{\|}$ $+1.10^{-3}$ at $413 \mathrm{~nm}$, whereas $\left.n_{410 \mathrm{~nm}}-n_{820 \mathrm{~nm}}=5.10^{-2}\right]$.

Phase matching may be obtained by periodic spatial modulation of the nonlinearity. ${ }^{11}$ This has been achieved in polymers by periodically modulating the poling field. ${ }^{12} \mathrm{As}$ such a setup is difficult to realize on a micrometer length scale, we have chosen a different approach. With UV light that falls within the CT absorption band, the NLO moieties in the polymer can be easily bleached, as is witnessed by the strong decrease of their CT absorption band after irradiation (Fig. 4). This results in a strong loss of nonlinearity of the polymer, which is largely irreversible. Al-

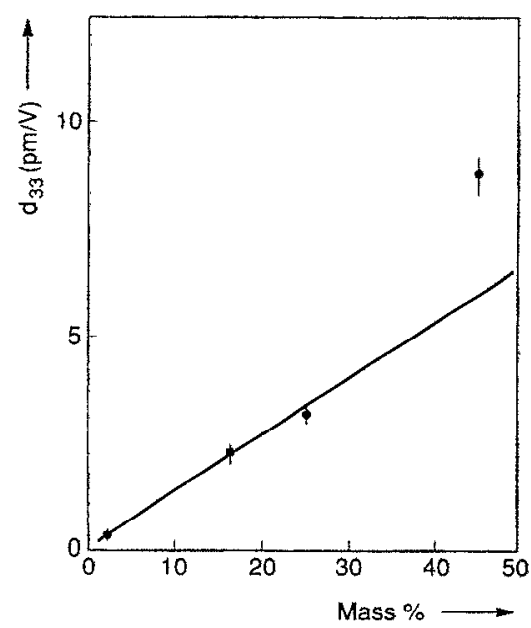

FIG. 2. Second-order susceptibility vs NLO chromophore concentration at $820 \mathrm{~nm}$ fundamental wavelength, shortly after poling at $1.2 \mathrm{MV} / \mathrm{cm}$. Lowest concentration was a solution, others were copolymers. A linear dependence is indicated.

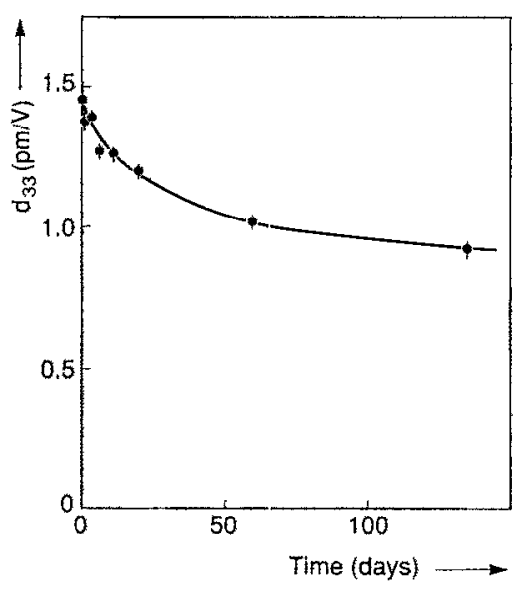

FIG. 3. Second-order susceptibility vs time at $1064 \mathrm{~nm}$ fundamental wavelength of the $25 \%$ copolymer (II) after poling at $1.2 \mathrm{MV} / \mathrm{cm}$, when stored in a dry environment. The curve is only meant to guide the eye.

though the exact mechanism for the bleaching has not yet been established, a likely route is trans to cis isomerization, followed by ring closure, resulting in a molecule with a much smaller hyperpolarizability. Using gratingwise photobleaching, we have accomplished the desired spatial modulation and we have observed quasi-phase matching. Further work on this method is in progress. As we have also succeeded in defining channel waveguides in these polymers by photobleaching, an entirely "photographic" definition of a frequency doubling device seems feasible.

In conclusion, we have described the design and characterization of methylmethacrylate copolymers with 4-alkoxy-4'-alkylsulfone stithene sidechains as nonlinear optical moieties, which are suited for frequency doubling of 820 nm diode lasers.

We gratefully acknowledge stimulating and helpful discussions with A. H. J. Venhuizen, E. E. Havinga, W. ten Hoeve, and W. Hynberg.

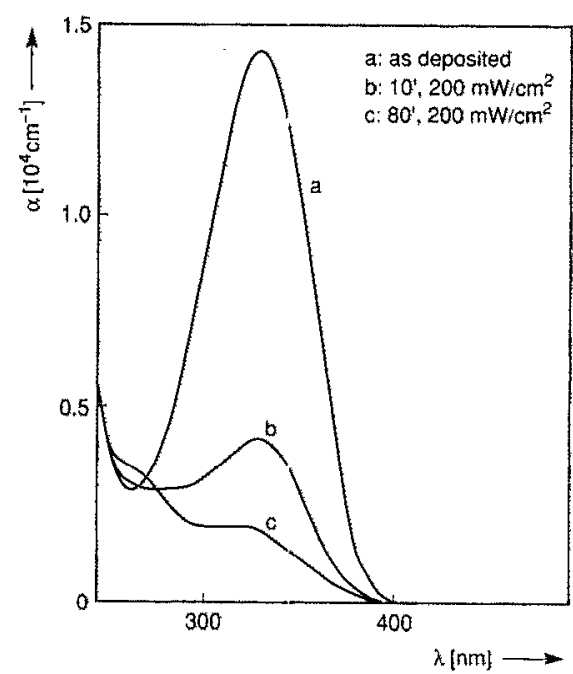

FIG. 4. Absorbance $v$ wavelength of the $25 \%$ copolymer (II) before (curve $a$ ) and after UV irradiation that causes bleaching of the NLO chromophore; curve $b$ was measured after 10 min of irradiation with 200 $\mathrm{mW} / \mathrm{cm}^{2}$ at $\lambda=365 \mathrm{~nm}$, curve $c$ after $80 \mathrm{~min}$ of irradiation. 
'E. E. Havinga and P, v. Pelt, Ber. Bunsenges, Phys. Chem. 83, 816 (1979).

'S. J. Lalama, J. Sohn, and K. D. Singer, SPIE Proc. 578, 168 (1985).

${ }^{3}$ Nonlinear Optical Properties of Organic Molecules and Crystals, D. S. Chemla and J. Zyss, eds. (Academic, New York, 1986), Vol. 1, Chaps. 11-7, 11-8.

${ }^{4}$ K. D. Singer, J. E. Sohn, and S. J. Lalama, Appl. Phys. Lett. 49, 248 (1986).

'L. T. Cheng, W. Tam, G. R. Meredith, G. L. J. A. Rikken, and E. W. Meijer, SPIE Proc, 1047, 61 (1989).

"S. Nijhuis, G. L. J. A. Rikken, E. E. Havinga, W. ten Hoeve, H. Wynberg, and E. W. Meijer, J. Chem. Soc. Chem. Comm. 1093 (1990)
${ }^{7}$ T. -N. Ding and E. Garmire, Appl. Opt. 22, 3177 (1983).

${ }^{8}$ R. B. Comizolli, J. Electrochem. Soc. 134, 425 (1987).

${ }^{9}$ J. I. Thackara, G. F. Lipscomb, M. A. Stiller, A. J. Thickner, and R. Lytel, Appl. Phys. Lett. 52, 1031 (1988).

${ }^{10}$ W. H. G. Horsthuis and G. J. M. Krijnen, Appl. Phys. Lett. 55, 616 (1989).

${ }^{11}$ J. A. Armstrong, N. Bloembergen, J. Ducuing, and P. S. Pershan, Phys. Rev. 127, 1918 (1962).

${ }^{12}$ G. Khanarian and D. Haas, US Patent 4.865.406; G. Khanarian, R. Norwood, D. Haas, B. Feuer, and D. Karim, Appl. Phys. Lett. 57, 977 (1990). 